\title{
The effect of different macromineral intakes on mineral metabolism of sport horses
}

\author{
Branislav Gálik ${ }^{1}$ Daniel Bíro ${ }^{1}$, Marko Halo$^{2}$, Miroslav Juráček ${ }^{1}$, Milan Šimko ${ }^{1}$, \\ Peter Massányi ${ }^{3}$, Michal Rolinec ${ }^{1}$ \\ ${ }^{1}$ Department of Animal Nutrition, ${ }^{2}$ Department of Animal Husbandry, Faculty of Agrobiology \\ and Food Resources, ${ }^{3}$ Department of Animal Physiology, Faculty of Biotechnology and Food Sciences, \\ Slovak University of Agriculture in Nitra, Slovak Republic
}

Received January 13, 2012

Accepted March 7, 2012

\begin{abstract}
The aim of the study was to analyze the effect of different intakes of macroelements from feed on the mineral blood profile of sport horses. In the experiment which lasted for 12 months (6 months for each of the two periods), 14 sport horses with 2 types of feed rations were monitored. The blood was collected at the beginning of the experiment and every 2 months (three blood collections for each period). Feed rations had a negative effect on Ca (3.40 $\mathrm{mmol} \cdot \mathrm{I}^{-1}$ and $\left.3.32 \mathrm{mmol} \cdot \mathrm{l}^{-1}\right)$ and $\mathrm{K}\left(3.2 \mathrm{mmol} \cdot \mathrm{l}^{-1}\right.$ and $\left.2.98 \mathrm{mmol} \cdot \mathrm{l}^{-1}\right)$ concentrations in equine serum obtained from the second and third blood collection, respectively. Concentration of $\mathrm{P}\left(1.28 \mathrm{mmol} \cdot \mathrm{l}^{-1}\right.$ and $\left.1.20 \mathrm{mmol} \cdot \mathrm{l}^{-1}\right)$ in equine serum obtained from the second and third blood collection, respectively, was higher $(P<0.05)$ compared to the first blood collection. Concentrations of $\mathrm{Mg}$ and $\mathrm{Na}$ were in reference intervals. In the $2^{\text {nd }}$ period of experiment, feed rations were adjusted based on individual requirements of the monitored horses; the proportion of the mineral ingredient in the feed rations was lowered. More balanced concentrations of $\mathrm{Ca}, \mathrm{Mg}, \mathrm{Na}$ and $\mathrm{K}$ were detected in equine blood serum as a result of lower intake of the minerals from feed; the concentration of $\mathrm{P}$ was, except for one case, higher than in the $1^{\text {st }}$ period. We observed a positive effect of individual ration compositions based on the results of blood mineral profile. The study describes for the first time the effect of a high and adequate long-term intake of macroelements on their concentrations in sport horses' blood serum.
\end{abstract}

Nutrition, equine, macroelements, influence, metabolic tests

The demand for information related to the nutrition and feeding management of horses has increased due to their popularity and with improvements in nutrition in general (NRC 2007). Equine nutrition influences complex of biochemical and physiological processes. It is one of the major limiting factors for equine performance (Halo et al. 2009). In the last 20 years, there has been increased interest in the role of minerals in equine nutrition. Calcium and phosphorus are well recognized for their acting on the bones; sodium, potassium and chloride play a role of electrolytes. Relatively few studies have focused on magnesium (Meyer and Coenen 2003; NRC 2007). Minerals play a critical role in the health of horses (NRC 2007); however, feeds are generally deficient in mineral content or they contain only small spectrum of minerals (Gálik et al. 2009a). Diets traditionally used for horse nutrition are often imbalanced in mineral nutrients, especially regarding macroelement concentrations (Fradinho et al. 2006). Mineral nutrient utilization from feeds is different. Incorrect feeding management increases the occurrence of gastric problems (Bezděková et al. 2008).

One of the ways for the control of horses' mineral profile are metabolic tests. Many studies have focused on metabolic tests in horse nutrition. The right interpretations of haematological and mineral blood indicators depend also on feeding conditions, training and time of blood sampling (Yashiki et al. 1995). In Europe, many studies have been conducted on the influence of the training process on horse performance (i.e. Jan iszew ska et al. 2004) but few have focused on horse nutrition. Results of the effect of different 
mineral intake on the metabolic profile were reported e.g. by Cymbaluk and Christison (1989), Vervuert et al. (2006) and Hala et al. (2008). Cymbaluk and Christison (1989) reported that lower $\mathrm{P}$ intake than required had a significantly negative effect on $\mathrm{P}$ serum concentration. Similar tendency in $\mathrm{Ca}, \mathrm{P}$ and $\mathrm{Mg}$ serum concentrations affected by adequate, moderately high and high mineral intake published Vervuert et al. (2006).

The aim of the present study was to assess the effect of different daily intake of macroelements on the analyzed mineral profile of sport horses.

\section{Materials and Methods}

The study was performed in the Riding Centre of the Slovak University of Agriculture in Nitra. In the experiment, 14 clinically healthy warm blood male sport horses (geldings of Slovak warm blood breed), were monitored during medium exercise (daily work form 4 to $6 \mathrm{~h}$ in basic and light level of sport exercise). The average body weight of the monitored horses was $518 \pm 65 \mathrm{~kg}$, the average age was $6.8 \pm 3$ years. Horses were stabled in boxes (individually) in the riding centre with water supplied ad libitum. The feed ration was comprised of crushed oat, grass hay and mineral feed mixture. The proportion of feed rations is shown in Table 1; the ration of crushed oat and grass hay was individually different, however, the dose of mineral premix was the same for all horses $(60 \mathrm{~g}$ per day and horse). Proportion of the mineral premix was in the $1^{\text {st }}$ period of experiment according the feed manufacturer.

Table 1. Characteristics of horse feed rations in the first and second period of the experiment. Concentrations of monitored minerals in used feeds are shown in Table 2. Horses were all fed manually $\times 2$ a day in the morning and in the evening; the remainings of feed from the previous

\begin{tabular}{lrcc}
\hline & \multicolumn{3}{c}{ Feed ration $(\mathrm{kg})$} \\
\cline { 2 - 4 } & Oats & Hay & MFM $(\mathrm{g})$ \\
\hline First period & $3-6$ & $7-10$ & 60 \\
Second period & $2.5-4$ & $6.5-10$ & $34-60$ \\
\hline
\end{tabular}

MFM - mineral feed mixture feeding were always removed from the feeding trough. Nutritional values of basic feed rations were: digestible energy (DE) $22.22 \mathrm{MJ} \cdot \mathrm{kg}^{-1}$ of dry matter, crude protein content (CP) $295.2 \mathrm{~g} \cdot \mathrm{kg}^{-1}$ of dry matter.

The time of monitoring the effect of mineral intake in feed on their concentration in horses' blood serum was divided into 2 periods. Each period lasted for 6 months. In the $1^{\text {st }}$ period, the obtained feed rations were analyzed and the daily intakes were compared with the recommended daily requirements of horses according to NRC (2007). The intake of minerals calcium (Ca), phosphorus (P), magnesium ( $\mathrm{Mg})$, sodium $(\mathrm{Na})$ and potassium $(\mathrm{K})$ in feed and their concentration in blood of horses was monitored. To determine the mineral profile in the blood of horses, vena jugularis was punctured. Blood was collected every 2 months; $\times 3$ per each period. Blood serum was obtained by centrifugation $(15 \mathrm{~min}, 805 \times g)$. Based on the results, the feed rations were optimized according to the NRC (2007); mainly the proportion of mineral premix was lowered (individually from 34 to $60 \mathrm{~g}$ by daily requirement). In the $2^{\text {nd }}$ period of experiment which lasted for the same time (6 months), the influence of nutritionally adjusted feed rations on the monitored indicators (concentration of macroelements) in blood serum of the same horses were monitored. In the $2^{\text {nd }}$ period of experiment, the blood was collected 2 months after feed ration adjustment and then every 2 months (in total $\times 3$ per period).

The content of organic and inorganic nutrients was determined at the Department of Animal Nutrition, Faculty of Agrobiology and Food Resources, Slovak University of Agriculture in Nitra; the standard laboratory methods were used (AOAC 2000). Digestible energy content was determined by calculation according to Zeyner and Kienzle (2002). The content of mineral substances in feed rations was determined by absorption spectrophotometry using the flame spectrophotometer AVANTA (Australia) according to standard laboratory methods and procedures (AOAC, 2000).

The concentrations of monitored macroelements in blood serum were determined using Ecoline kits and automatic analyzer Microlab 300 (Merck ${ }^{\circledR}$, Germany).

To calculate basic statistic characteristics, to determine significance of differences and to compare results of the analysis of variance, one-way ANOVA and $t$-test were performed at $P<0.05$. The SAS statistical software was used (SAS Inc., New York City, U.S.A.). 


\section{Results}

The daily intake of monitored macroelements was over the reference limit in the $1^{\text {st }}$ period of the experiment in all monitored horses, with the exception of potassium. In comparison with the recommended daily intake of $\mathrm{Ca}$ and $\mathrm{P}$, all the monitored horses were overfed. The average daily intake of $\mathrm{Ca}$ and $\mathrm{P}$ was $49.46 \mathrm{~g}$, and $42.86 \mathrm{~g}$, respectively. Concentration of $\mathrm{Ca}$ in serum was detected at the upper limit (Table 3). Significantly $(P<0.05)$ the lowest Ca concentration $\left(2.75 \mathrm{mmol} \cdot \cdot^{-1}\right)$ was found in the first blood collection. Concentration of $P$ ranged from 0.92 to $1.28 \mathrm{mmol}^{-1} l^{-1}$; concentrations were in the reference range $0.7-1.7 \mathrm{mmol} \cdot \mathrm{l}^{-1}$. Significant $(P<0.05)$ differences were found between the first and second and between the first and third blood collection. The analytically determined intake of $\mathrm{Mg}(16.20 \mathrm{~g})$ was higher than the daily requirement. However, taking into consideration the average $50 \% \mathrm{Mg}$ utilization from feedstuff, the $\mathrm{Mg}$ intake was only slightly over the limit. Concentration of $\mathrm{Mg}$ in serum ranged from 0.78 to $1.06 \mathrm{mmol} \cdot \cdot^{-1}$; the reference interval ranged from 0.9 to $1.2 \mathrm{mmol} \cdot \mathrm{l}^{-1}$ or from 0.7 to $1.1 \mathrm{mmol} \cdot \mathrm{l}^{-1}$. Significantly $(P<0.05)$ the lowest $\mathrm{Mg}$ serum concentration was detected in second collection $\left(0.78 \mathrm{mmol} \cdot \mathrm{l}^{-1}\right)$. Concentrations of $\mathrm{Na}$ during the $1^{\text {st }}$ period of the experiment were in a balance interval $\left(138.62-139.38 \mathrm{mmol} \cdot \mathrm{l}^{-1}\right)$. The average daily Na intake in the $1^{\text {st }}$ period of experiment was $280.01 \mathrm{~g}$. Serum concentration of $\mathrm{Na}$ was in the reference interval $\left(132-146 \mathrm{mmol} \cdot \mathrm{l}^{-1}\right)$. The daily intake of $\mathrm{K}$ from feed ration was substantially lower in comparison with the calculated daily requirement $(5.78 \mathrm{~g})$. In the first and second blood collection we found the concentration of $\mathrm{K}\left(2.98\right.$ and $3.2 \mathrm{mmol} \cdot \mathrm{l}^{-1}$, respectively $) \times 2$ lower compared to the reference range (3.5-5.5 mmol-1 $\left.\mathrm{l}^{-1}\right)$. However, detected $\mathrm{K}$ serum concentrations were within the reference interval $2.8-4.7 \mathrm{mmol} \cdot \mathrm{l}^{-1}$. Significantly $(P<0.05)$ the highest $\mathrm{K}$ concentration was found in the second blood collection.

Due to significant overfeeding of the monitored horses with macroelements, we adjusted the feed rations nutritionally so that they would meet all the nutrient requirements of the monitored horses to the highest possible extent in the $2^{\text {nd }}$ period of experiment. The average daily intake of $\mathrm{Ca}, \mathrm{P}, \mathrm{Mg}, \mathrm{Na}$ and $\mathrm{K}$ was $42.72 \mathrm{~g}, 37.07 \mathrm{~g}, 12.40 \mathrm{~g}, 249 \mathrm{~g}$ and $5.05 \mathrm{~g}$, respectively. Daily intakes of $\mathrm{Ca}, \mathrm{P}$ and $\mathrm{Mg}$ in the $2^{\text {nd }}$ period of experiment were lower as an effect of lower mineral premix proportion. In the $2^{\text {nd }}$ period of the experiment, we found a tendency of higher Ca concentration (3.34-3.55 mmol-1/-1) in the equine serum. The concentrations were higher than reference limits $\left(2.0-3.3 \mathrm{mmol} \cdot \mathrm{l}^{-1}\right)$. Despite the lower proportion of mineral feed additive in feed rations of the monitored horses, we did not detect its significant influence on the concentration of $\mathrm{Ca}$ and $\mathrm{Na}$ in the blood serum (Table 3). By adjusting feed rations, the proportion of mineral feed mixture was

Table 3. Mineral blood profile of horses in the first and second period of experiment with three blood samplings affected by higher macroelement intake (mean $\pm \mathrm{SD})$.

\begin{tabular}{lcccrr}
\hline $\begin{array}{l}\text { Blood } \\
\text { intake }\end{array}$ & $\mathrm{Ca}$ & $\mathrm{P}$ & $\mathrm{Mg}$ & $\mathrm{Na}$ & \multicolumn{1}{c}{$\mathrm{K}$} \\
\hline $\begin{array}{l}\text { First period } \\
1^{\text {st }}(\mathrm{n}=14)\end{array}$ & $2.75^{\mathrm{ab}} \pm 0.124$ & $0.92^{\mathrm{ab}} \pm 0.131$ & $1.06^{\mathrm{a}} \pm 0.167$ & $139.08 \pm 2.183$ & $3.2^{\mathrm{a}} \pm 0.282$ \\
$2^{\text {nd }}(\mathrm{n}=14)$ & $3.40^{\mathrm{a}} \pm 0.399$ & $1.28^{\mathrm{a}} \pm 0.203$ & $0.78^{\mathrm{ab}} \pm 0.098$ & $138.62 \pm 0.789$ & $3.72^{\mathrm{ab}} \pm 0.072$ \\
$3^{\text {rd }}(\mathrm{n}=14)$ & $3.32^{\mathrm{b}} \pm 0.259$ & $1.20^{\mathrm{b}} \pm 0.120$ & $1.01^{\mathrm{b}} \pm 0.094$ & $139.38 \pm 1.444$ & $2.98^{\mathrm{b}} \pm 0.156$ \\
Second period & & & & & \\
$1^{\text {st }}(\mathrm{n}=14)$ & $3.55 \pm 0.325$ & $1.07^{\mathrm{a}} \pm 0.138$ & $0.71^{\mathrm{a}} \pm 0.064$ & $136.74 \pm 1.606$ & $4.2^{\mathrm{a}} \pm 0.278$ \\
$2^{\text {nd }}(\mathrm{n}=14)$ & $3.34 \pm 0.313$ & $1.35^{\mathrm{a}} \pm 0.105$ & $0.94^{\mathrm{a}} \pm 0.074$ & $136.92 \pm 0.867$ & $3.89^{\mathrm{a}} \pm 0.130$ \\
$3^{\text {rd }}(\mathrm{n}=14)$ & $3.55 \pm 0.196$ & $1.07 \pm 0.920$ & $0.70 \pm 0.193$ & $136.76 \pm 1.18$ & $4.2 \pm 0.663$ \\
\hline
\end{tabular}

$\mathrm{Ca}$ - calcium, $\mathrm{P}$ - phosphorus, $\mathrm{Mg}$ - magnesium, $\mathrm{Na}$ - sodium, $\mathrm{K}$ - potassium (in $\mathrm{mmol} \cdot \mathrm{l}^{-1}$ ), $\mathrm{SD}$ - standard deviation Values with the same superscript in the column are significantly different at $P<0.05$ 
lowered and we achieved the optimization of $\mathrm{Ca}$ and $\mathrm{P}$ concentrations in blood serum of the monitored horses. Concentration of $\mathrm{P}$ in serum ranged from 1.07 (first and third blood collection) to $1.35 \mathrm{mmol} \cdot \mathrm{l}^{-1}$ (second blood collection). Significant $(P<0.05)$ differences in $\mathrm{P}$ concentrations were found between the first and second blood collection. Despite the individual adjustment of feed rations in the second period of the experiment, the concentrations of $\mathrm{Ca}, \mathrm{Mg}, \mathrm{Na}$ and $\mathrm{K}$ in the blood serum of horses were more balanced. In the actual conditions of sport horses breeding, we found significant dependence of adequate intake of inorganic nutrients on their concentration in blood serum. By the adjustment of feed rations based on individual nutritional requirements, we achieved more balanced concentrations of monitored macroelements in the blood serum of horses.

\section{Discussion}

A high intake of mineral substances has a depressive effect (Gálik et al. 2009b). Overfeeding animals with calcium results in hypercalcinaemia or hyperparathyreoidism (Vrzgula et al. 1990). The calculated intake of macroelements in our study was not in accordance with recommendations by NRC $(1989,2007)$. The daily requirements in the feed for geldings with the average body weight of $518 \pm 65 \mathrm{~kg}$ are $20.72 \pm 2.6 \mathrm{~g}$ for $\mathrm{Ca}$, $14.5 \pm 1.82 \mathrm{~g}$ for $\mathrm{P}, 7.77 \pm 1 \mathrm{~g}$ for $\mathrm{Mg}, 25.9 \pm 3.25 \mathrm{~g}$ for $\mathrm{K}$ and $10.36 \pm 1.3 \mathrm{~g}$ for Na (NRC 2007). In the $1^{\text {st }}$ period of the experiment, the proportion of mineral feed mixture was the same for all horses. This had a negative effect on the level of some minerals in equine blood serum. In our study, we detected $\mathrm{Ca}$ concentrations within the tolerable range in two sample collections. The reference values for Ca are 2.6-3.3 $\mathrm{mmol} \cdot \mathrm{l}^{-1}$ (Boyd 1984) or 2.0-3.0 mmol·1-1 (Vrzgula et al. 1990). Similar Ca concentrations in equine blood serum found in our study were reported also by Piccione et al. (2008). Vervuert et al. (2006) reported $\mathrm{Ca}$ concentrations in equine serum ranging from 3.14 to $3.18 \mathrm{mmol} \cdot \mathrm{l}^{-1}$ in the trial with adequate, moderately high and high calcium and phosphorus intake. Lower concentrations of $\mathrm{Ca}$ in blood serum were detected by Cymbaluk and Christison (1989) who monitored the effect of different energetic concentrations and phosphorus contents on blood chemistry in a similar experiment.

The concentration of $\mathrm{P}$ in the equine blood serum in our study was $\times 2$ lower than the reference limit $\left(1.2-2.0 \mathrm{mmol} \cdot \mathrm{l}^{-1}\right)$ reported by Vrzgula et al. (1990). The utilization of $\mathrm{P}$ and also other nutrients is lowered by the effect of high Ca intake from feed ration (Gálik et al. 2009b; McDonald et al. 2002). Boyd (1984) detected P in the equine serum at a concentration ranging from 0.7 to $1.7 \mathrm{mmol} \cdot \mathrm{l}^{-1}$.

The concentration of $\mathrm{Mg}$ in the blood serum of horses was at the reference limit $\left(0.7-1.1 \mathrm{mmol}^{-1} \mathrm{l}^{-1}\right)$ reported by Boyd (1984); however, in the marginal values of the reference limit $\left(0.9-1.2 \mathrm{mmol} \cdot \mathrm{l}^{-1}\right)$ reported by Vrzgula et al. (1990) except for the second blood collection $\left(0.78 \mathrm{mmol} \cdot \mathrm{l}^{-1}\right)$. Similar $\mathrm{Mg}$ serum concentrations as in our study were found by Vervuert et al. (2006).

Reference values of $\mathrm{K}$ in the blood serum of sport horses ranged from 3.5 to $5.5 \mathrm{mmol} \cdot \mathrm{l}^{-1}$ (Vrzgula et al. 1990) or from 2.8 to $4.7 \mathrm{mmol} \cdot \mathrm{l}^{-1}$ (Boyd 1984). Fradinho et al. (2006) recorded the effect of supplementation of mineral feed additive for horses. In our study, we found comparable concentrations of mineral substances in the blood of horses to those reported by Halo et al. (2008) describing the influence of stress on training exercise of horses.

In the $2^{\text {nd }}$ period of the experiment, horses were fed with lower proportion of mineral feed mixture that resulted in more balanced mineral serum concentrations. Simultaneously, we also observed an important economical effect. In the $2^{\text {nd }}$ period of the experiment, the mineral feed dosage was lower, and this effect did not influence negatively the blood concentrations of mineral substances. 


\section{Acknowledgements}

This work was supported by Grant Agency of the Slovak Ministry of Education, Science, Research and Sport and Slovak Academy of Sciences (projects n. 1/0662/11).

\section{References}

AOAC 2000: Official methods of analysis: Method 968.08. Association of official analytical chemists Inc, Washington, 40

Bezděková B, Jahn P, Vyskočil M 2008: Gastric ulceration, appetite and feeding practices in standardbred racehorses in the Czech Republic. Acta Vet Brno 77: 603-607

Boyd JW 1984: The interpretation of serum biochemistry tests results in domestic animals. Vet Clin Path. Veterinary Practice Publishing Co., 13 p.

Cymbaluk NF, Christison Gl 1989: Effects of dietary energy and phosphorus content on blood chemistry and development of growing horses. J Anim Sci 67: 951-958

Fradinho MJ, Ferreira-Dias G, Mateus L, Santos-Silva MF, Agrícola R, Barbosa M, Abreu JM 2006: The influence of mineral supplementation on skeleton formation and growth in Lusitano foals. Livestock Sci 104: 173-181

Gálik B, Bíro D, Juráček M, Šimko M, Gyöngyová E 2009a: The concentrations of mineral elements in different conserved feeds. Krmiva 51: 223-227

Gálik B, Halo M, Bíro D, Polyaková L 2009b: Influence of nutrition on metabolic performance of sport horse. Acta Fytotech Zootech 12: 135-137

Hala Abou-Zeina AA, Soad Nasr M, Amena Ibrahim M, El-Sissi A, Ezzo HM 2008: Evaluation of oral minerals supplementation for treatment on mineral deficiency in Arabian Mares. American-Eurasian J Agric Environ Sci 4: 451-461

Halo M, Strapák P, Hollý A, Mlyneková E, Kovalčík E, Horný M 2008: Influence of stress on the training process of the horses. Central Europ Agricul 9: 217-224

Halo M, Massányi P, Juhás P, Vavrišínová K 2009: Biochemical parameters in horses in relation to nutrition and training process. Acta Fytotech Zootech 12: 138-140

Janiszewska J, Ignor J, Cieśla A 2004: Modifying influence of 11-months training on results of timidity test of young half bred stallions. Arch Tierz 47: 7-13

McDonald P, Edwards RA, Greenhalgh JFD, Morgan CA 2002: Animal nutrition. Pearson Education Ltd., Harlow, 693 p.

Meyer H, Coenen M 2003: Feeding of horses: Current trends in nutrition. Ikar, Praha, 256 p.

NRC (2007): Nutrient requirements of horses. National Research Council, Washington, $341 \mathrm{p}$.

NRC (1989): Nutrient requirements of horses. National Research Council, Washington, $97 \mathrm{p}$.

Pioccione G, Assenza A, Fazio F, Bergero D, Caola G 2008: Daily rhythm of serum vitamin D-metabolites, calcium and phosphorus in horses. Acta Vet Brno 77: 151-157

Vervuert I, Stanik K, Coenen M 2006: Effects of different levels of calcium and phosphorus intake on calcium homeostasis in exercising horses. Equine Vet J Sl 36: 659-663

Vrzgula L, Alijev AA, Barej W, Bartko P, Bouda J, Dvorak R, Garbašanski P, lllek J, Jagoš P, Karsai F, Kóňa E, Kováč G, Nedkova L, Sokol J, Sova Z, Schäfer M 1990: Failures of livestock metabolism and their prevention. Príroda, Bratislava, $503 \mathrm{p}$.

Zeyner A, Kienzie E 2002: A method to estimate digestible energy in horse feed. J Nutr 132: 1771-1773

Yashiki K, Kusunose R, Tagaki S 1995: Diurnal variations of blood constituents in young Thoroughbred horses. J Equi Sci 6: 91-97 